\title{
Dynamic transcriptional regulation of autocrine/paracrine igfbp1, 2, 3, 4, 5, and 6 in the skeletal muscle of the fine flounder during different nutritional statuses
}

\author{
Diego Safian*, Eduardo N Fuentes*, Juan Antonio Valdés and Alfredo Molina \\ Laboratorio de Biotecnologia Molecular, Departmento de Ciencias Biologicas, Facultad de Biologia, Universidad Andres Bello, Avenida Republica 217 \\ 8370146 Santiago, Chile \\ (Correspondence should be addressed to A Molina; Email: amolina@unab.cl) \\ *(D Safian and E N Fuentes contributed equally to this work)
}

\begin{abstract}
The IGF-binding proteins (IGFBPs) play a dual role in the regulation of the activity and bioavailability of IGFs in different tissues. Diverse evidence has shown that IGFBPs can inhibit and/or potentiate IGF actions. In this study, igfbp 1, 2, $3,4,5$, and 6 were isolated in the fine flounder, a flat fish species that shows slow growth and inherent Gh resistance in muscle. Subsequently, the expression of all igfbps was assessed in the skeletal muscle of flounder that underwent different nutritional statuses. igfbp 1 was not expressed in muscle during any of the nutritional conditions, whereas igfbp 3 and igfbp 5 were the lowest and the highest igfbps expressed respectively. A dynamic expression pattern was found in all the igfbps expressed in skeletal muscle, which depended on the nutritional status and sampling period. During the fasting
\end{abstract}

period, igfbp 2, 4, and 5 were downregulated, whereas igfbp 3 was upregulated during part of the fasting period. The restoration of food modulated the expression of the igfbps dynamically, showing significant changes during both the long- and short-term refeeding. igfbp 3 and igfbp 6 were downregulated during short-term refeeding, whereas igfbp 5 was upregulated, and igfbp 2 and igfbp 4 remained stable. During long-term refeeding, the expression of igfbp 2, 4, 5, and 6 increased, while igfbp 3 remained unchanged. In conclusion, this study shows for the first time the isolation of all igfbps in a single fish species, in addition to describing a dynamic nutritional and time-dependent response in the expression of igfbps in the skeletal muscle of a nonmammalian species.

Journal of Endocrinology (2012) 214, 95-108

\section{Introduction}

The insulin-like growth factor (IGF) system regulates somatic growth in vertebrates and is integrated by the IGFs (IGF1 and IGF2), the IGF receptors (IGF1R and IGF2R), and the IGF-binding proteins (IGFBPs; Duan et al. 2010). IGFs are mainly synthesized by the liver; however, they can be locally produced in numerous tissues, including skeletal muscle acting in an autocrine/paracrine fashion (Velloso 2008). In particular, muscle-derived IGF1 has been proposed as the main regulator of growth in mammals (Sjögren et al. 1999, Yakar et al. 1999). As in mammals, some recent evidence has shown that in fish, local Igf1 is of importance in muscle growth (Eppler et al. 2007, Fox et al. 2010, Fuentes et al. 2012a). The dynamic of the biological actions of IGFs is modulated by the binding of these growth factors with either specific membrane receptors and/or the IGFBPs. The IGFBPs are a family of proteins that show high affinity for IGFs and are composed of six members, denominated IGFBP1-6 (Jones \& Clemmons 1995). In circulation, the IGFBPs bind to IGFs, transporting and increasing their half-life by preventing their proteolytic degradation (Hwa et al. 1999). The IGFBPs have a higher affinity for IGF than IGF receptors; thus, they are implicated in the modulation of the activity and bioavailability of IGFs in different tissues (Clemmons 1998). Numerous evidences indicate that IGFBPs can inhibit and/or potentiate IGF actions depending on the physiological context (Duan \& Xu 2005, Duan et al. 2010). IGFBPs can also be synthesized in different cell types and tissues, exerting an important role in the local regulation of IGFs (Jones \& Clemmons 1995, Firth \& Baxter 2002, Duan et al. 2010). Particularly, in skeletal muscle, the igfbps are expressed differentially during myogenesis and are implicated in the modulation of muscle growth, showing liganddependent and -independent actions (James et al. 1993, Ewton \& Florini 1995, Bayol et al. 2000, Awede et al. 2002, Foulstone et al. 2003, Ren et al. 2008).

In fish, several studies have described the isolation of individual igfbps (Duan et al. 1999, Maures \& Duan 2002, Chen et al. 2004, Kamangar et al. 2006, Bower et al. 2008, Li et al. 2009, Pedroso et al. 2009a, Peterson \& Waldbieser 2009, Wang et al. 2009, Dai et al. 2010, Rahman \& Thomas 2011). 
However, until now, the isolation and assessment of the expression patterns of all six igfbps in the same species have not been achieved. Previous studies on the biology of Igfbps in fish have shown that Igfbps regulate embryonic development (Duan et al. 1999, Kajimura et al. 2005, Li et al. 2009, Wang et al. 2009) and exert ligand-dependent and -independent mechanisms (Dai et al. 2010, Zhong et al. 2011), as well as showing that Igfbps are modulated by Gh treatment (Duan et al. 1999, Cheng et al. 2002, Chen et al. 2004, 2010, Pedroso et al. 2009b), oxygen availability (Kajimura et al. 2005, Kamei et al. 2008, Rahman \& Thomas 2011, Sun et al. 2011), reproduction (Kamangar et al. 2006, Chen et al. 2010), and nutrition (Gabillard et al. 2006, Bower et al. 2008, Li et al. 2009, Pedroso et al. 2009a, Peterson \& Waldbieser 2009, Amaral \& Johnston 2011, Macqueen et al. 2011). Nevertheless, studies on local muscle-derived igfbps (autocrine/ paracrine) have been scarce and have recently shown contrasting results, reflecting a complex physiology of Igfbps and suggesting that intricate patterns of regulation have evolved between and within teleost lineages (Gabillard et al. 2006, Bower et al. 2008, Amaral \& Johnston 2011, Macqueen et al. 2011).

The fine flounder (Paralichthys adspersus (P. adspersus)) is an endemic flatfish species of the southern East Pacific that shows a slow growth rate and poor food intake even under favorable nutritional conditions (Fuentes et al. 2012a,b). Previously, we have described part of the molecular and endocrine basis accounting for the slow growth of this teleost species, showing that fine flounder present an inherent Gh resistance in skeletal muscle, which results in low basal levels of musclederived Igf1 (Fuentes et al. 2012a,b). Thus, the low production of autocrine/paracrine Igf1 was the responsible mechanism for growth deficit in this species; however, the regulation of the main modulators of Igf1 availability and actions, such as the Igfbps, remained unknown as did their possible consequences on growth in this species. Thus, use of this intriguing fish model will allow us to go further in the understanding of igfbps' physiology in fish, particularly in the understanding of local igfbps produced in the muscle. In this context, the aim of this work was to assess a detailed time course changes in the expression pattern of all six igfbps in skeletal muscle in the fine flounder, evaluating two contrasting nutritional periods, fasting and refeeding (short and long term). In order to achieve this goal, six igfbps were previously isolated.

\section{Materials and Methods}

\section{Animals, sampling, and experimental design}

Three-year-old juvenile fine flounder ( $P$. adspersus) with an average weight of $300 \pm 10 \mathrm{~g}$ and length of $27 \pm 2 \mathrm{~cm}$ were maintained under natural temperature and photoperiod conditions corresponding to the geographic location of CIMARQ $\left(33^{\circ} 13^{\prime} \mathrm{S} ; 71^{\circ} 38^{\prime} \mathrm{W}\right)$ during the spring season of 2009 in the southern hemisphere. Fish were randomly divided into two tanks and acclimatized for 2 weeks under satiety feeding conditions. At the beginning of the experiment (week 0), food was withheld from one group for 3 weeks (experimental (EXP)), inducing a nutritionally catabolic state of fasting. Then, fish were subjected to a 4-week satiety refeeding period, returning the fish to an anabolic state. The other group (control (CTRL)) was fed until satiety throughout the 7-week study. Samples were obtained weekly over the trial to study long-term regulation and dynamics of the igfbps' expression in skeletal muscle. At the beginning of the refeeding period, fish were sampled at 2,4 , and $24 \mathrm{~h}$ in order to assess short-term changes in the expression of igfbps. In order to study the expression of the igfbps in different tissues (e.g. tissues from gills, intestine, stomach, spleen, heart, liver, and red and white muscle) of the fine flounder, tissues were collected from nonmanipulated flounder maintained in the conditions mentioned earlier. For each sampling point, three individuals were sampled $(n=3)$. Sampling was performed under anesthesia (3-aminobenzoic acid ethyl ester, $100 \mathrm{mg} / \mathrm{l}$ ) and tissue was subsequently collected. Tissue was frozen immediately in liquid nitrogen and stored at $-80{ }^{\circ} \mathrm{C}$ until processing. The study adhered to animal welfare procedures and was approved by the Bioethical Committees of the Universidad Andres Bello and the National Commission for Scientific and Technological Research of the Chilean government.

\section{$R N A$ extraction and $c D N A$ synthesis}

Total RNA was extracted from tissue using the RNeasy Mini Kit (Qiagen) following the manufacturer's recommendations. RNA was quantified using NanoDrop technology with the Epoch Multi-Volume Spectrophotometer System (BioTek, Winooski, VT, USA). Assessment of RNA quality was performed by electrophoresis on a $1 \cdot 2 \%$ formaldehyde agarose gel containing ethidium bromide. Only RNAs with an A260:A280 ratio between 1.9 and $2 \cdot 1$ were used for cDNA synthesis. Residual genomic DNA was removed using the genomic DNA wipeout buffer included in the Quantitect RT kit (Qiagen). Subsequently, $800 \mathrm{ng}$ RNA was reverse transcribed into cDNA for $30 \mathrm{~min}$ at $42{ }^{\circ} \mathrm{C}$ using the manufacturer's recommendations.

\section{Isolation and identification of igfbps in fine flounder}

Once high-quality cDNA was obtained from the liver as described previously, igfbp 1, 2, 3, 4, 5, and 6 were isolated and deposited in the GenBank (Table 1). Primers used for obtaining the sequences of igfbps were designed by multiple alignments of sequences from fish species using ClustalW, identifying evolutionary conservative regions (Table 1). PCR was performed using $1 \mu \mathrm{l}$ cDNA template, $10 \mu \mathrm{l}$ PCR buffer $10 \times, 200 \mu \mathrm{M}$ each dNTP, $500 \mathrm{nM}$ each primers, $0 \cdot 3 \mu \mathrm{lTaq}$ DNA polymerase $(12 \mathrm{U} / \mu \mathrm{l})$ (Promega), and RNAse-free water to a final volume of $50 \mu \mathrm{l}$. Primers used for isolating the 
Table 1 Primer sequences for cloning and quantitative PCR (qPCR) assay of the igfbps of the fine flounder $(\mathbf{M}=\mathrm{A} / \mathrm{C}, \mathbf{R}=\mathrm{A} / \mathrm{G}, \mathbf{Y}=\mathrm{C} / \mathrm{T}, \mathbf{S}=\mathrm{G} / \mathrm{C}$, and $\mathbf{K}=\mathrm{G} / \mathrm{T})$. Amplicon size $(\mathrm{pb})$, qPCR efficiencies $(E(\%))$, coefficient of standard curves $\left(R^{2}\right)$, and GenBank accession number are also shown

\begin{tabular}{|c|c|c|c|c|c|c|}
\hline Gene & Primer & Sequence $\left(5^{\prime}-3^{\prime}\right)$ & Size (bp) & $\boldsymbol{E}(\%)$ & $\boldsymbol{R}^{2}$ & Accession number \\
\hline \multirow[t]{4}{*}{ igfbp1 } & Forward cloning & GAKCCKGGMTGYGGCTGCT & & & & JN635274 \\
\hline & Reverse cloning & TGTCACAGTTGGGGAGGTAGA & & & & \\
\hline & Forward qPCR & GCCAAGAGGACACTGAAGGT & 226 & $99 \cdot 5$ & $0 \cdot 986$ & \\
\hline & Reverse gPCR & GGGAGGTAGAAGGTGGTGAA & & & & \\
\hline \multirow[t]{4}{*}{ igfbp2 } & Forward cloning & TTCCGMTGTCCRAGYTGCAC & & & & JN126038 \\
\hline & Reverse cloning & GACATSTTRCACTGTTTSAG & & & & \\
\hline & Forward qPCR & TTGGCATTGGCAAGAGTCC & 172 & $102 \cdot 6$ & $0 \cdot 998$ & \\
\hline & Reverse gPCR & TCTGTTATCСTCAGCGGTCA & & & & \\
\hline \multirow[t]{4}{*}{ igfbp3 } & Forward cloning & AAACСКСТGCAGGСКСТGСТ & & & & JN126039 \\
\hline & Reverse cloning & AGGCTGTCCRTACTTGTCCA & & & & \\
\hline & Forward qPCR & CCTGAGTATGGTCCСTGTCG & 80 & $99 \cdot 3$ & $0 \cdot 953$ & \\
\hline & Reverse gPCR & ССTCTGGGGTTGAGAATGTC & & & & \\
\hline \multirow[t]{4}{*}{ igfbp4 } & Forward cloning & GAGAGGGAKGTGGARGAGAA & & & & JN126040 \\
\hline & Reverse cloning & TCACAGTTGGGKATGGGGAT & & & & \\
\hline & Forward qPCR & CAGCGATGGACAGGCAGGATG & 189 & 95 & 0.993 & \\
\hline & Reverse gPCR & GTAGCTCAGCACGACATGGA & & & & \\
\hline \multirow[t]{4}{*}{ igfbp5 } & Forward cloning & KCACGCSCTTCTCCAYGG & & & & JN126041 \\
\hline & Reverse cloning & AGAKGGYTTACACTGCTTGC & & & & \\
\hline & Forward qPCR & GCAAGGAGCAGAAGAGGAAG & 164 & $99 \cdot 3$ & $0 \cdot 997$ & \\
\hline & Reverse gPCR & CAGAGCCATTACACGAGAAGT & & & & \\
\hline \multirow[t]{4}{*}{ igfbp6 } & Forward cloning & GAGAGCCCTGTGGGGTGTA & & & & JN635275 \\
\hline & Reverse cloning & CGGCACTGCTTTTTCCTGTA & & & & \\
\hline & Forward qPCR & GCCAAGCACAGCAGGACTA & 124 & $100 \cdot 2$ & $0 \cdot 997$ & \\
\hline & Reverse qPCR & CCAGACСССТСАGGACACT & & & & \\
\hline
\end{tabular}

six igfbps in the fine flounder are listed in Table 1. Thermal cycling conditions were as follows: initial denaturation of $10 \mathrm{~min}$ at $95^{\circ} \mathrm{C}$, followed by 40 cycles of $30 \mathrm{~s}$ at $95^{\circ} \mathrm{C} ; 30 \mathrm{~s}$ at $53{ }^{\circ} \mathrm{C}($ igfbp 3$), 56{ }^{\circ} \mathrm{C}($ igfbp 1 and igfbp 2$)$, or $58^{\circ} \mathrm{C}($ igfbp $4-6)$; $30 \mathrm{~s}$ at $72{ }^{\circ} \mathrm{C}$; and a final extension of $10 \mathrm{~min}$ at $72^{\circ} \mathrm{C}$. PCR products were loaded on a $1.5 \%$ agarose gel and then isolated and purified using the Wizard SV Gel and PCR Clean-Up System (Promega).

Specific PCR products were cloned into a TOPO TA Cloning system (Invitrogen) using the manufacturer's recommendations. In short, PCR products were ligated into the T/A pCR4-TOPO vector (Invitrogen) and subsequently One Shot TOP10 competent Escherichia coli (Invitrogen) was transformed with the vector. Individual colonies were cultured and plasmids were isolated and purified using the Qiagen Plasmid Purification (Qiagen) and subsequently sequenced.

\section{Phylogenetic analyses and logos alignment of Igfbps in fish}

In order to further prove that the partial sequences isolated corresponded to six different Igfbps in the fine flounder sequence, alignment and construction of the phylogenetic tree using ClustalW and MEGA 5 were performed (Tamura et al. 2011). Owing to the lack of full-length sequences, phylogenetic or evolutionary relationships were not evaluated in this phylogenetic tree. For distance analysis, the neighbor-joining approach with the $\mathrm{p}$-distance method and bootstraping (1000 replicates) as support for subgroup on the phylogenetic tree was used.

Logos alignment was performed using the variable central linker (L) domain. The alignment was carried out using LogoBar, a program that allows graph visualization of protein Logos alignment with gaps (Pérez-Bercoff et al. 2006).

\section{Assessment of igfbps expression}

Primer design Primer designs for quantitative PCR (qPCR) of igfbps were based on partial sequences previously obtained and are listed in Table 1 . In order to get high-quality primers and avoid secondary structure (hairpins, homo-, and cross-dimers), Amplifx 1.5.4 (http://ifrjr.nord.univ-mrs.fr/ AmplifX-Home-page) and Primer 3 (http://frodo.wi.mit. edu/primer3/) programs were used. Subsequently, primer pairs were validated using the software NetPrimer (http://www.premierbiosoft.com/netprimer/).

Quantitative real-time PCR All the procedures were carried out according to the protocol outlined by Bower \& Johnston (2010), with minor modification. All qPCR assays were carried out to comply with the Minimum Information for Publication of Quantitative Real-Time PCR Experiments (MIQE) guidelines (Bustin et al. 2009).

Total RNA extraction and cDNA synthesis from different tissues (i.e. igfbps expression in different tissue analysis) and skeletal muscle of all sampling points (i.e. igfbps during fasting 
and refeeding analysis) were performed as described previously (See RNA extraction and cDNA synthesis). qPCR was performed using the Stratagene MX3005P QPCR system (Stratagene, La Jolla, CA, USA). Each qPCR reaction mixture contained $7 \cdot 5 \mu \mathrm{l}$ Brilliant II SYBR green master mix (Agilent Technologies, Stratagene), $6 \mu \mathrm{cDNA}$ (40-fold dilution), $250 \mathrm{mM}$ each primers, $5 \mu \mathrm{M}$ ROX, and RNAsefree water to a final volume of $15 \mu \mathrm{l}$. Amplifications were performed in triplicate with the following thermal cycling conditions: initial activation at $95^{\circ} \mathrm{C}$ for $10 \mathrm{~min}$, followed by 40 cycles of $30 \mathrm{~s}$ at $95^{\circ} \mathrm{C}, 30 \mathrm{~s}$ at $58^{\circ} \mathrm{C}$, and $30 \mathrm{~s}$ at $72^{\circ} \mathrm{C}$. CTRL reactions included a no template control (NTC) and a CTRL without reverse transcriptase $(-\mathrm{RT})$. SYBR green fluorescence was always recorded during the linear phase of cycling. In order to confirm the presence of a single PCR product, dissociation curve analysis of the PCR products was performed. Products were also evaluated by electrophoresis on a $2 \%$ agarose gel to confirm that a single product was amplified. With the purpose of estimating the assay's efficiency, twofold dilution series were created from a cDNA pool. Efficiency values were estimated from the slope of the curve following the equation efficiency: $E=10\left(-1 /\right.$ slope $^{-1}$ (Table 1$)$. qPCR data were analyzed using $C_{\mathrm{t}}$ values, which were then exported and processed into a Microsoft Excel-based Software application (Q-Gene; Muller et al. 2002). For the analysis of igfbps expression in different tissue, graphs were expressed as arbitrary units (A.U.) using as a reference gene $18 \mathrm{~S}$ rRNA (18S). For the analysis of igfbps expression during fasting and refeeding, graphs are expressed as a fold change over basal levels found at the beginning of the trial (week 0) for long-term changes. Shortterm changes are expressed as fold changes over fasting levels at the end of this period (third week). $40 \mathrm{~S}$ ribosomal protein S30 (FAU) was used as the most stable reference gene (Fuentes EN, Safian D, Valdes JA \& Molina A 2012, unpublished results).

Heat map summary and hierarchical clustering In order to establish relationships among relative expression profiles of the igfbps with the rest of the components of the Igf system, a heat map summary and hierarchical clustering analysis of gene expression were performed using
Permutmatrix (Caraux \& Pinloche 2005). In order to place the expression pattern of igfbps into a global context into the Igf system in muscle, we used the expression of previously published igf1, igf2, and igf1r using the same sampling points (Fuentes et al. 2012a,b). Clustering and seriation were based on Pearson's correlation coefficient of $z$-score-normalized relative transcript abundance values (scaled from 0 to 1 ). McQuitty's method of hierarchical clustering was used.

Statistical analysis Statistical analysis used to study differences in gene expression was based on an advanced linear model. This model was the general linear model (GLM) followed by Tukey's analyses as post-test. All statistical analyses were performed using the STATISTICA 7 Software (Tulsa, OK, USA).

\section{Results}

Isolation of igfbps

Logos alignment showed a low identity when the L-domain of all Igfbps of the fine flounder (fflGFBPs) was compared among them (Tables 2 and 3). The Logos alignment showed that Igfbp1, 2, and 3 are very variable among teleost fish whereas Igfbp 4, 5, and 6 are highly conserved among teleost fish (Fig. 1). Using the partial sequence of all Igfbps, including part of the $\mathrm{N}$ - and C-domains, equal results were found (data not shown). In order to further corroborate the identity of all six fflGFBPs, a phylogenetic tree using the L-domain from all Igfbps was constructed, showing that all Igfbps are clustered in different branches with a respective Igfbp (Supplementary Figure 1, see section on supplementary data given at the end of this article).

\section{Expression of igfbps in different tissues of the fine flounder}

igfbp 1 and igfbp 2 were predominantly expressed in the liver, showing low expression levels in the other tissues (Fig. 2A and B). Particularly, igfbp 1 was not expressed in red and white muscle, whereas igfbp 2 was not detected in the stomach (Fig. 2A and B). igfbp 3 and igfbp 4 were detected in all analyzed tissues, but igfbp 3 was predominantly expressed in the

Table 2 Amino acid sequence identity between the L-domain of the lgfbps of rainbow trout (rtigfbp). Accession number for the rtigfbps: igfbp1 (NM_001124561), igfbp2 (NM_001124649), igfbp3 (NM_001124557), igfbp4 (DQ146967), igfbp5 (NM_001124652), and igfbp6 (NM_001124560)

\begin{tabular}{|c|c|c|c|c|c|c|}
\hline & rtigfbp1 & rtigfbp2 & rtigfbp3 & rtigfbp4 & rtigfbp5 & rtigfbp6 \\
\hline ffigfbp1 & $58 \cdot 3$ & $16 \cdot 7$ & $6 \cdot 3$ & $12 \cdot 5$ & $20 \cdot 8$ & $4 \cdot 2$ \\
\hline ffigfbp2 & $7 \cdot 6$ & $37 \cdot 7$ & $37 \cdot 9$ & $9 \cdot 1$ & $15 \cdot 2$ & $6 \cdot 1$ \\
\hline ffigfbp3 & $13 \cdot 6$ & $19 \cdot 8$ & $18 \cdot 3$ & $14 \cdot 8$ & $19 \cdot 8$ & $12 \cdot 3$ \\
\hline ffigfbp4 & $7 \cdot 1$ & $16 \cdot 1$ & $16 \cdot 1$ & $82 \cdot 3$ & $14 \cdot 4$ & $16 \cdot 1$ \\
\hline ffigfbp5 & $12 \cdot 9$ & $21 \cdot 2$ & $15 \cdot 3$ & $9 \cdot 4$ & $80 \cdot 2$ & $5 \cdot 6$ \\
\hline ffigfbp6 & $13 \cdot 8$ & $12 \cdot 5$ & $4 \cdot 1$ & $21 \cdot 0$ & $8 \cdot 0$ & $79 \cdot 3$ \\
\hline
\end{tabular}

Numbers in bold indicate comparison between respective orthologs sequences. 
Table 3 Amino acid sequence identity between the L-domain of the lgfbps of the fine flounder (fflgfbp)

\begin{tabular}{|c|c|c|c|c|c|c|}
\hline & ffigfbp1 & ffigfbp2 & ffigfbp3 & ffigfbp4 & ffigfbp5 & ffigfbp6 \\
\hline ffigfbp1 & 100 & $11 \cdot 1$ & $16 \cdot 6$ & $14 \cdot 6$ & $14 \cdot 6$ & $10 \cdot 4$ \\
\hline ffigfbp2 & & 100 & $18 \cdot 2$ & $16 \cdot 7$ & $13 \cdot 6$ & $5 \cdot 0$ \\
\hline ffigfbp3 & & & 100 & $14 \cdot 8$ & $11 \cdot 1$ & $16 \cdot 7$ \\
\hline ffigfbp4 & & & & 100 & $19 \cdot 6$ & $16 \cdot 1$ \\
\hline ffigfbp5 & & & & & 100 & $9 \cdot 4$ \\
\hline ffigfbp 6 & & & & & & 100 \\
\hline
\end{tabular}

liver, whereas igfbp 4 was highly expressed in the intestine, stomach, and spleen (Fig. 2C and D). igfbp 5 expression was also ubiquitous, but particularly highly expressed in the stomach and heart (Fig. 2E). Likewise, igfbp 6 was detected in all tissues assessed, showing high expression in gill, intestine, stomach, and heart and low expression in spleen, red muscle, white muscle, and liver (Fig. 2F).

Expression of igfbps in skeletal muscle during fasting and refeeding

Different results in the gene expression of fine flounder igfbps in skeletal muscle were found, which depended on the feeding status. igfbp1 was not detected in the skeletal muscle after 40 cycles.

igfbp 2 mRNA levels decreased during fasting in the EXP group, showing almost three and 12-fold lower expression than basal levels ( 0 week) after 2-3 weeks of food withdrawal respectively (Fig. 3A, Supplementary Figure 2A, see section on supplementary data given at the end of this article). After 6 weeks of refeeding, igfbp 2 mRNA returned to basal levels in the EXP group and passed these levels at the seventh week (Fig. 3A, Supplementary Figure 2A, see section on supplementary data given at the end of this article). During short-term refeeding in the EXP group, igfbp 2 expression decreased even further during $2 \mathrm{~h}$ of refeeding; however,

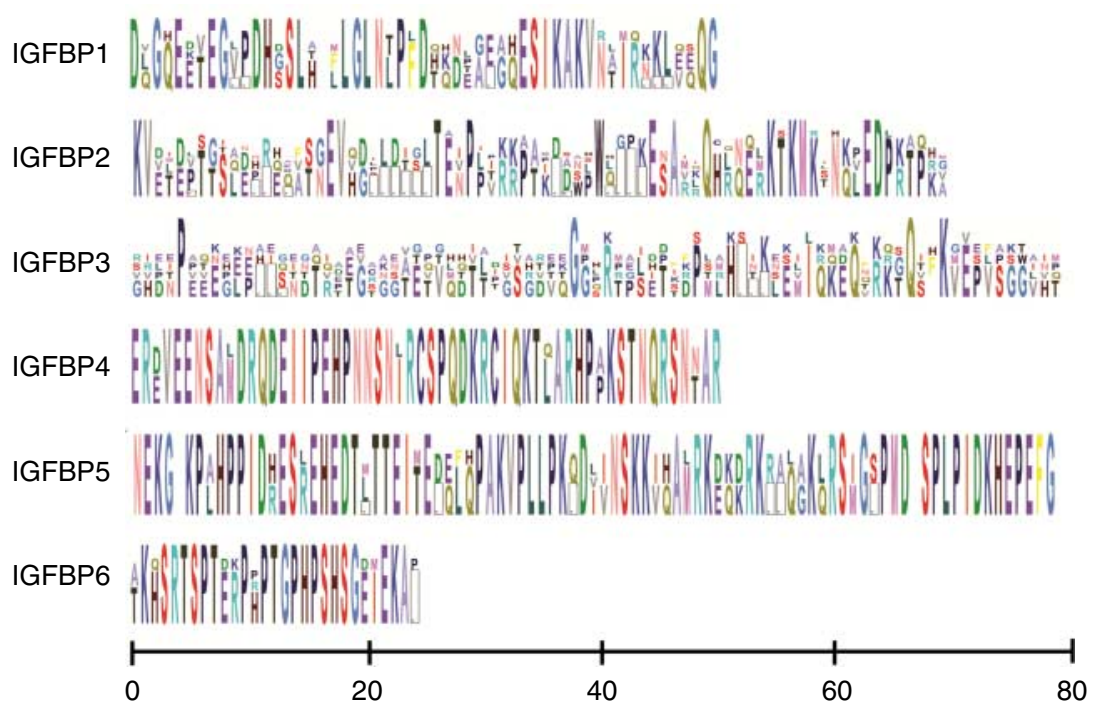

Figure 1 Sequence logo alignment for the L-domain of amino acid sequence of fine flounder Igfbps and other teleost fish. Accession number for Igfbp1: turbot (AEB96249), yellowtail (ACD10797), Atlantic salmon (NP_001117096), rainbow trout (NP_001118033), and zebra fish (CAC44453.1). Accession number for Igfbp2: turbot (ADW77214), yellowtail (ACD11355), carp (ACM47497), Atlantic salmon (NP_001117097), European sea bass (ACB15195), and zebra fish (AAF23123). Accession number for Igfbp3: zebra fish (NP_991314), rainbow trout (NP_001118029), and yellowtail (ACD11356). Accession number for Igfbp4: fugu (NP_001139534), Atlantic salmon (NP_001133058), and Arctic charr (ADM93279.1). Accession number for lgfbp5: yellowtail (ACD11357), Atlantic salmon (NP_001117121), rainbow trout (NP_001118124), zebra fish (AAM51549), and rainbow smelt (ACO09073). Accession number for Igfbp6: Atlantic salmon (NP_001117122), rainbow trout (NP_001118032), zebra fish (NP_001154874), and Arctic charr (ADM93278). Full colour version of this figure available via http://dx.doi.org/10.1530/JOE-12-0057. 


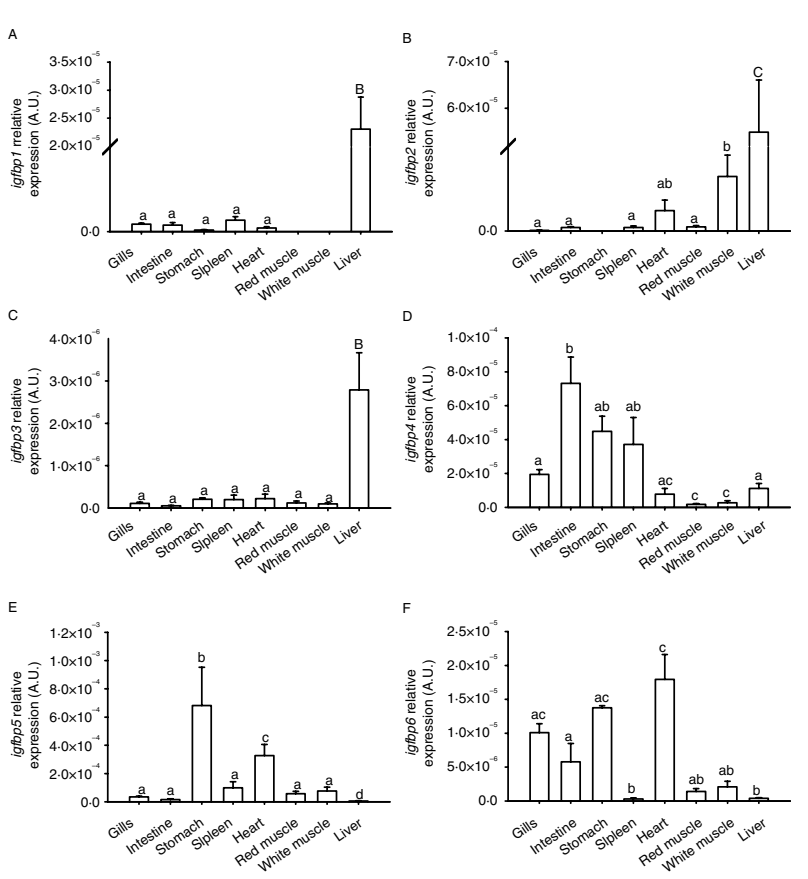

Figure 2 mRNA contents of igfbp1 (A), igfbp2 (B), igfbp3 (C), igfbp4 (D), igfbp5 (E), and igfbp6 (F) in different tissues of the fine flounder. Values are expressed as mean (S.E.M.; $n=3$ per each tissue). A GLM followed by Tukey's analysis as a post-test indicates significant differences. Different letters indicate significant differences. Lowercase letters show a significance of $P<0 \cdot 05$ and upper case letters show a significance of $P<0 \cdot 01$ (A, B, C, D, E and F).

after 4 h, igfbp 2 expression returned to fasting levels (Fig. 4A, Supplementary Figure 2A, see section on supplementary data given at the end of this article). igfbp 2 mRNA contents did not vary significantly in the CTRL fish during the trial (Figs 3A and 4A insert).

igfbp 3 mRNA levels in the EXP group increased significantly during 1 and 2 weeks of fasting (four- and three fold respectively), but, interestingly, the expression of igfbp 3 declined and then returned to basal levels at the end of fasting (Fig. 3B, Supplementary Figure 2B, see section on supplementary data given at the end of this article). During long-term refeeding in the EXP group, igfbp 3 expression returned to basal levels. During short-term refeeding in the EXP group, igfbp 3 expression decreased even further (fivefold; Fig. 4B, Supplementary Figure 2B, see section on supplementary data given at the end of this article). igfbp 3 mRNA contents did not vary significantly in the CTRL fish during the trial (Figs 3B and 4B insert).

igfbp 4 mRNA levels in the EXP group were significantly downregulated during the third week of fasting (sevenfold lower mRNA levels; Fig. 3C, Supplementary Figure 2C, see section on supplementary data given at the end of this article). During long-term refeeding in the EXP group, igfbp 4 expression was resumed after the fourth week and subsequently showed an increase over basal levels, which was significant at the seventh week $(3 \cdot 5$-fold higher than basal level; Fig. 3C, Supplementary Figure 2C, see section on supplementary data given at the end of this article). No significant changes were observed after $24 \mathrm{~h}$ of refeeding in the EXP group (Fig. 4C, Supplementary Figure 2C, see section on supplementary data given at the end of this article). Igfbp 4 mRNA contents did not vary significantly in the CTRL fish during the trial (Figs 3C and 4C insert).

igfbp 5 mRNA levels decreased after 3 weeks of fasting in the EXP group (fourfold lower expression than 0 week; Fig. 3D, Supplementary Figure 2D, see section on supplementary data given at the end of this article). During refeeding in the EXP group, igfbp 5 mRNA levels increased, finding almost $2 \cdot 5$-fold higher mRNA levels at 6 weeks than at the beginning of the trial ( 0 week). Rapid changes in gene expression of igfbp 5 in the EXP group were observed during the first $24 \mathrm{~h}$ of refeeding, with almost 4.5-fold higher mRNA levels than the fasting period (Fig. 4D, Supplementary Figure 2D, see section on supplementary data given at the end of this article). igfbp $5 \mathrm{mRNA}$ contents did not vary significantly in the CTRL fish during the trial (Figs 3D and 4D insert).

igfbp6 mRNA levels in the EXP group did not change significantly during fasting (Fig. 3E, Supplementary Figure 2E, see section on supplementary data given at the end of this article). During refeeding, particularly during short-term refeeding in the EXP group, igfbp 6 mRNA levels declined rapidly, remaining low during the first $24 \mathrm{~h}$ (Fig. 4E, Supplementary Figure 2E, see section on supplementary data given at the end of this article). igfbp 6 mRNA contents did not vary significantly in the CTRL fish during the trial (Figs 3E and 4E insert).

High differences were observed when analyzing the differences in the mRNA contents among all igfbps in skeletal muscle of the fine flounder during basal, fasting, and refeeding conditions. igfbp 1 was not detected in skeletal muscle in any of the nutritional conditions assessed. igfbp 2 and igfbp 6 mRNA contents were similar in basal, fasting, and refeeding conditions (Fig. 3F). igfbp3 expression was the lowest of all igfbps (except igfbp1; Fig. 3F). igfbp 4 contents were not significantly different in basal and fasting conditions but were significantly different during refeeding. igfbp 5 was always the most abundant of all igfbps, independent of nutritional status and sampling period (Fig. 3F). At the beginning of the shortterm refeeding ( $0 \mathrm{~h}$, fasting), igfbp $2,3,4$, and 6 contents were not significantly different, with the exception of igfbp 5 , which was the most abundant (Fig. 4F). After $24 \mathrm{~h}$ of refeeding, igfbp 2, 4, and 6 expression was similar, whereas igfbp 3 and igfbp 5 expression was the lowest and the highest respectively (Fig. 4F).

\section{Heat map summary and hierarchical clustering}

Hierarchical clustering of Igf system expression during longterm fasting and refeeding showed different variations among different components of the Igf system. During long-term 

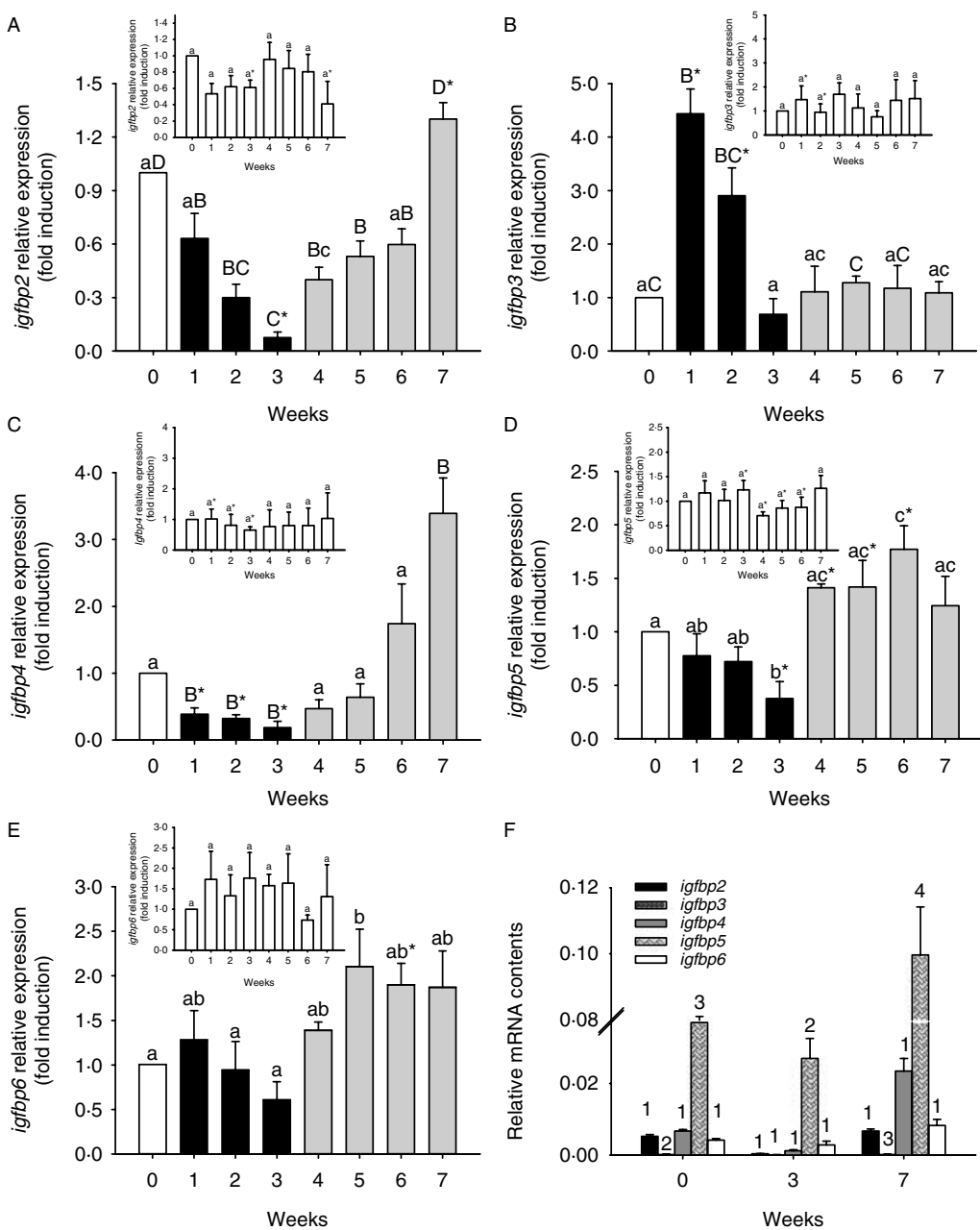

$\mathrm{F}$

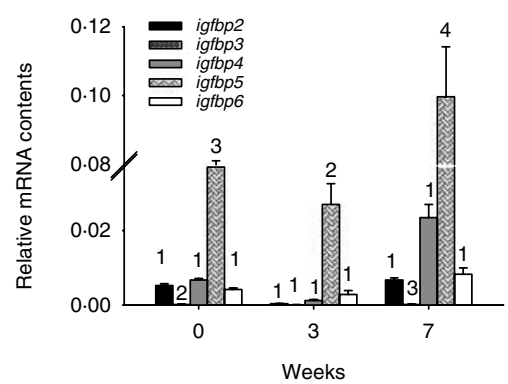

Figure 3 Transcriptional regulation of the igfbps in the skeletal muscle of the fine flounder during long-term fasting and refeeding. Relative expression of igfbp2 (A), igfbp3 (B), igfbp4 (C), igfbp5 (D), and igfbp6 (E) in muscle. White, black, and gray bars represent periods of feeding, fasting, and refeeding respectively. Data are presented as changes from initial conditions ( 0 week) and expressed as mean \pm S.E.M. $(n=3$ per each time). A GLM followed by Tukey's analysis as a post-test indicates significant differences. Different letters indicate significant differences. Lowercase letters show a significance of $P<0.05$ and upper case letters show a significance of $P<0.01$ (A, B, C, $\mathrm{D}$ and $\mathrm{E})$. Different numbers of relative mRNA contents of the igfbps represent significant differences $(P<0 \cdot 05 ; \mathrm{F})$. Asterisks indicate a significant difference between the CTRL and EXP groups at a given sampling point. CTRL group of each igfbps was added as an insert.

refeeding, two clades were found; the first clade showed a close relation and covariation in the expression of igf 1 and igfbp 2, 4, 5, and 6 (Fig. 5A), whereas igf1 showed more similitude with igfbp 5 and igfbp 6 than with igfbp 2 and igfbp 4 . The second clade clustered igf2, igf $1 r$, and igfbp 3 . During short-term refeeding, two clades were found. The first clade showed two subgroups; the first subgroup clustered igf 2 , igf1r, igfbp 2 , and igfbp 6 while the second subgroup clustered igfbp 3 and igfbp 4. The second clade clustered igf 1 and igfbp 5 (Fig. 5B).

\section{Discussion}

Isolation of igfbp1, 2, 3, 4, 5, and 6 in the fine flounder

In fish, the igfbps have been isolated from different models (Bower et al. 2008, Li et al. 2009, Pedroso et al. 2009a, Peterson \& Waldbieser 2009, Rahman \& Thomas 2011); however, the isolation and assessment of gene expression of the six igfbps in a single teleost had not been achieved until now. Kamangar et al. (2006) claimed the isolation of the six igfbps in rainbow trout. Nevertheless, in this publication, 

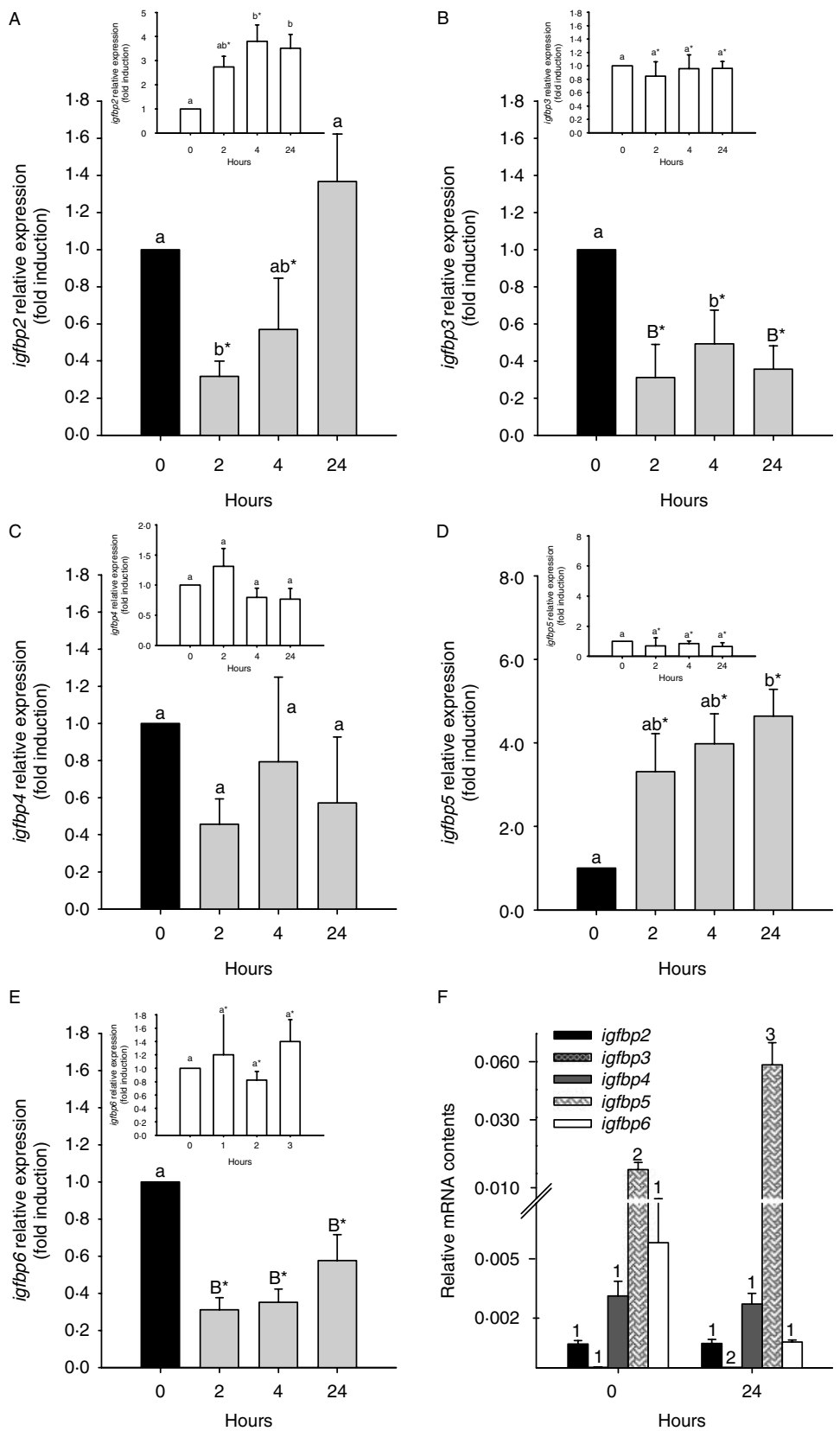

Figure 4 Transcriptional regulation of the igfbps in the skeletal muscle of the fine flounder during short-term refeeding. Relative expression of igfbp2 (A), igfbp3 (B), igfbp4 (C), igfbp5 (D), and igfbp6 (E) in muscle. White, black, and gray bars represent periods of feeding, fasting, and refeeding respectively. Data are presented as changes from fed initial conditions ( 0 week) and expressed as mean \pm s.E.M. ( $n=3$ per each time). A GLM followed by Tukey's analysis as a post-test indicates significant differences. Different letters indicate significant differences. Lowercase letters show a significance of $P<0 \cdot 05$ and upper case letters show a significance of $P<0.01$ (A, B, C, D and E). Different numbers in relative mRNA contents of the igfbps represent significant differences $(P<0 \cdot 05)$ (F). Asterisks indicate a significant difference between the CTRL and EXP groups at a given sampling point. CTRL group of each igfbps was added as an insert. 
A

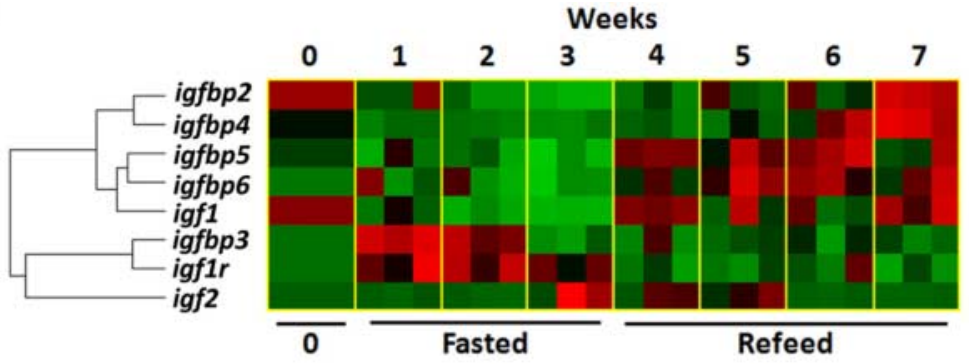

B

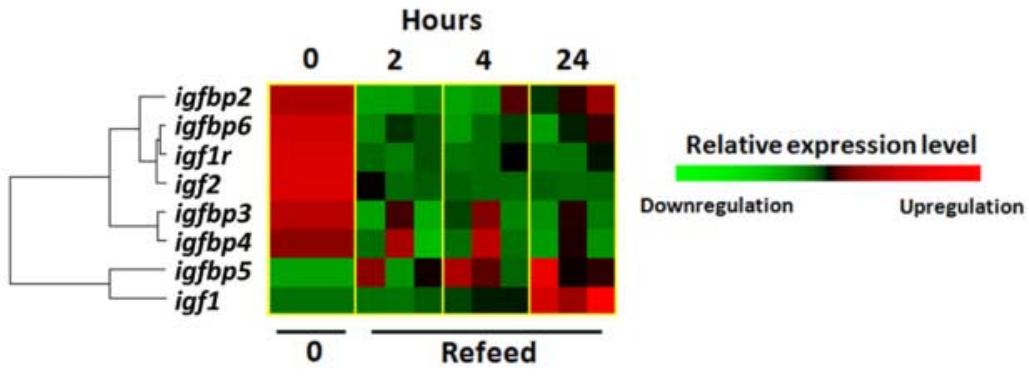

C

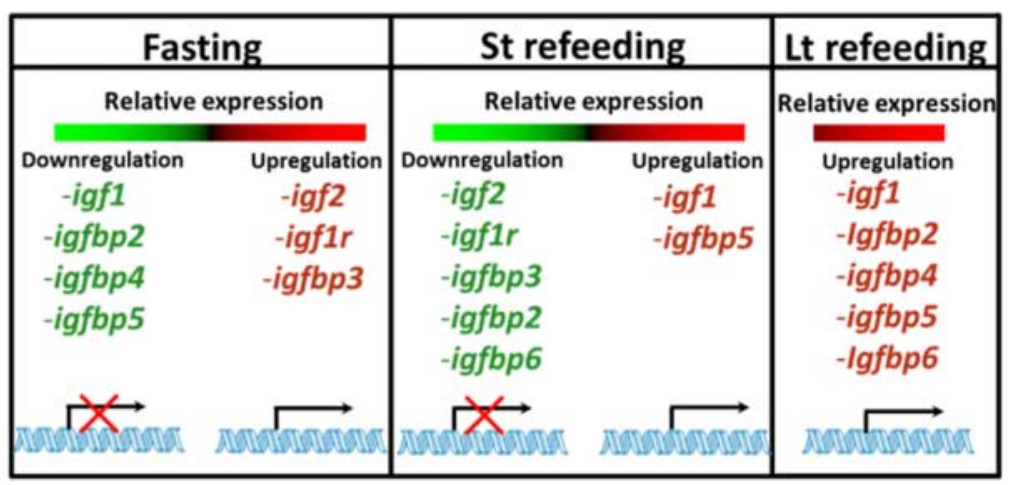

Figure 5 Summary of igfbps gene expression in the skeletal muscle of the fine flounder during fasting and refeeding. Heat map summary and hierarchical clustering of the $l g f$ system expression in the skeletal muscle of the fine flounder during long-term fasting and refeeding $(A)$ and short-term refeeding (B). In the heat map, red and green colors indicate upregulation and downregulation of gene expression during long-term fasting and refeeding and short-term refeeding. Schematic diagram summarizing gene expression pattern of the igfbps during fasting, short-term (St), and long-term refeeding (Lt; C). Full colour version of this figure available via http://dx.doi.org/10.1530/JOE-12-0057.

igfbp 3 was misnamed, with the igfbp 2 paralog 2 being the real igfbp isolated (Bower et al. 2008, Rodgers et al. 2008, Ocampo Dasa et al. 2011). The similarity among different Igfbps and/or other related proteins has been a common problem in the correct identification of Igfbps (Rodgers et al. 2008). All Igfbps have a common structure with a highly conserved N-terminal (also known as IGFBP domain), a conserved C-terminal domain (also known as thyroglobulin type-1 domain), and an internal variable L-domain (Duan \& Xu 2005). Moreover, whole genome duplication of teleost has triggered that teleosts often have two copies of each igfbps, which is shown to have different expression pattern (Kamei et al. 2008, Zhou et al. 2008, Wang et al. 2009, Bower \& Johnston 2010, Dai et al. 2010). In this study, we were unable to isolate paralogs for the igfbps in the fine flounder. Genomic resources would be a helpful methodology to try to isolate paralogs in this species, considering that until now all paralogs for igfbps have been identified in model fish models either with genome-sequenced (e.g. zebra fish and takifugu) or with EST sequence database (e.g. Atlantic salmon or rainbow trout), whereas in nonmodel fish, just one copy of the igfbps have been found (Atlantic croaker, carp, yellowtail, etc.; Cheng et al. 2002, Pedroso et al. 2009a, Peterson \& Waldbieser 2009, Rahman \& Thomas 2011, Sun et al. 2011). Comparing the ffgfbps, a very low identity was found, corroborating that they correspond to different Igfbps. In general, the six individual fflgfbps have a high identity with their orthologs. However, the fflgfbp3 showed a very low 
identity with the rtIgfbp3, highlighting that the fflgfbp3 is not the Igfbp2 paralog (Kamangar et al. 2006). In fact, when fflgfbp 3 is compared with other orthologs, a higher identity is found. Also by phylogenetic analysis, the fflgfbps are clustered separately in different branches, grouping each of the fflgfbps with their respective orthologs.

\section{Expression of Igfbp in different tissues of the fine flounder}

IGFBPs are synthesized mainly in the liver; however, they can also be synthesized in different tissues, regulating the IGF actions in an autocrine/paracrine fashion (Jones \& Clemmons 1995, Firth \& Baxter 2002, Duan et al. 2010). Fine flounder igfbp 1 and igfbp 2 are predominantly expressed in the liver with lower expression in other tissue, which is consistent with the previous findings in other fish species (Maures \& Duan 2002, Kamangar et al. 2006, Kamei et al. 2008, Pedroso et al. 2009a). Igfbp 1 is not detected in red and white muscles, similar to the previous reports in other fish species (Maures \& Duan 2002, Gabillard et al. 2006, Bower et al. 2008, Kamei et al. 2008, Pedroso et al. 2009a). On the other hand, igfbp2 is highly expressed in the liver of fine flounder. Recently, in Chinook salmon, Igfbp2 was shown to be the most abundant Igfbp into circulation system (Shimizu et al. 2011); this coincides with our results pointing out that liver is the major organ for igfbp 2 synthesis. Likewise, igfbp 3 is highly expressed in the liver, but it is also detected in all the tissues assessed, according to the previous reports on tilapia (Cheng et al. 2002) and zebra fish (Chen et al. 2004). Similar to other fish species, igfbp 4, 5, and 6 are ubiquitously expressed in different tissues of fine flounder; interestingly, these Igfbps are expressed low in liver, despite this tissue being considered the main source of all Igfbps in fish (Kamangar et al. 2006, Li et al. 2009, Pedroso et al. 2009a, Wang et al. 2009). Altogether, these results suggest that Igfbps could be regulating the actions of local Igfs in the fine flounder.

Transcriptional regulation of igfbps in the skeletal muscle during fasting and refeeding

Igfbps regulate the half-life of circulating Igfs as well as modulating their availability and biological activity, either inhibiting or potentiating Igf's actions depending on the EXP conditions, cell type, tissue, species, and physiological context (Wood et al. 2000, Zhou et al. 2004, Ning et al. 2006, 2008, Ren et al. 2008, Dai et al. 2010, Amaral \& Johnston 2011). Therefore, in the present work, the results were analyzed according to the physiological context of using two contrasting nutritional conditions: a catabolic period of fasting that leads to muscle atrophy followed by an anabolic period of refeeding that leads to hypertrophy of muscle. The fine flounder was used as a model, which is a fish that presents an inherent low production of muscle-derived Igf1 in muscle, which is responsible for growth deficiency in this species (Fuentes et al. 2012a,b).
The igfbp 1 is not detected in skeletal muscle, although it is highly expressed in the liver, which is concordant with the previous studies on fish (Maures \& Duan 2002, Gabillard et al. 2006, Bower et al. 2008, Kamei et al. 2008, Pedroso et al. 2009a). Nevertheless, a recent report by Amaral \& Johnston (2011) described that igfbp 1 is expressed in skeletal muscle of zebra fish and is regulated by nutrition, increasing during fasting and rapidly returning to basal levels during refeeding. The fact that igfbp 1 is upregulated during fasting has been associated with a negative role in growth in both fish and mammals (Maures \& Duan 2002, Kajimura et al. 2005, Kajimura \& Duan 2007). However, the effects caused by the absence of igfbp 1 expression in muscle of the fine flounder and other teleost fish are unknown and may be indicating a mechanism of fine regulation of local Igfs, independent of Igfbp1.

Mammalian IGFBP2 has been shown to both inhibit and potentiate IGF actions depending on cellular context (Duan $\& \mathrm{Xu} 2005)$. Studies on Igfbp 2 in fish have pointed out that this binding protein is a growth inhibitory protein, regulating Igf1 bioavailability (Duan et al. 1999, Wood et al. 2005). Few reports have described the dynamic of muscle-derived igfbp 2 . In $\mathrm{C} 2 \mathrm{C} 12$ cell cultures, igfbp 2 mRNA levels decrease with serum reduction (Bayol et al. 2000). In the muscle of fine flounder, igfbp 2 mRNA levels decrease during fasting and return to basal levels during long-term refeeding, in agreement with a previous report on the muscle of rainbow trout (Gabillard et al. 2006). In contrast, other recent reports have shown that igfbp2 expression increases during fasting, supporting the negative role of this binding protein (Bower et al. 2008, Macqueen et al. 2011).

In mammals, IGFBP3 is the major circulating IGFBP in plasma, transporting and extending the half-life of IGF1 (Firth \& Baxter 2002, Yamada \& Lee 2009, Domené et al. 2011). Locally produced IGFBP3 shows a different dynamic in muscle. This binding protein is not the most abundant IGFBP in muscle and shows both IGF-dependent actions by stimulating myoblast differentiation (Foulstone et al. 2003), IGF-independent actions, and suppressing cell proliferation (Pampusch et al. 2003). In fish, the role of Igfbp3 in skeletal muscle has not been defined, and no studies have investigated its expression during fasting and refeeding. The ffigfbp 3 was the least expressed of all the six igfbps. This coincides with the inherent Gh resistance and low basal production of local igf1 (Fuentes et al. 2011). igfbp 3 in fish is regulated by Gh and has been shown to decrease in hypophysectomized striped bass (Siharath et al. 1995) and increase with Gh injections in tilapia and yellowtail (Cheng et al. 2002, Pedroso et al. 2009b); therefore, low levels of igfbp 3 in skeletal muscle of the fine flounder may be associated with an impairment in Gh actions, preventing its expression in this tissue. Interestingly, igfbp 3 was the only binding protein upregulated during fasting, suggesting a negative role of this binding protein in muscle.

In mammals, IGFBP4 is considered a strong inhibitor of the anabolic action of IGFs (Ning et al. 2008); however, this binding protein also shows positive effects (Ning et al. 2008). 
Autocrine/paracrine IGFBP4 in muscle has also been associated with both negative actions, by inhibiting IGF1and IGF2-stimulated proliferation and differentiation (Damon et al. 1998, Ewton et al. 1998), and positive actions, by being upregulated concomitant with igf1 during muscle hypertrophy (Awede et al. 1999, 2002) and myoblast proliferation (Ewton \& Florini 1995). In teleost fish, an elevated correlation between igfbp 4 , which is highly expressed during proliferation, and myog, myoD, and $m y f 5$ in myogenic cell has been described (Bower \& Johnston 2010). Also in this study, both Igf1 and amino acids synergistically stimulate the expression of igfbp 4 (Bower \& Johnston 2010). In vivo studies on fish skeletal muscle have shown that igfbp 4 is constitutively upregulated during nutritionally favorable anabolic periods (Gabillard et al. 2006, Bower et al. 2008, Macqueen et al. 2011), coinciding with the present results. Interestingly, when different populations of the Arctic charr were assessed, dwarf fish expresses less igfbp 4 in muscle in basal conditions than normal-sized fish, and during refeeding, the expression of this binding protein was twofold lower in dwarfs than in normal-sized Arctic charr (Macqueen et al. 2011). In the fine flounder, igfbp 4 expression is also similar to that of igf1 long-term fasting and refeeding but not during short-term refeeding, suggesting that Igfbp4 may be a pro-myogenic molecule, as has been suggested previously in fish (Bower et al. 2008, Macqueen et al. 2011).

Igfbp 5 is the most conserved gene of the IGFBP family and is predominantly synthesized in skeletal muscle, similar to the present results (James et al. 1993, Kamangar et al. 2006, Dai et al. 2010). Despite some reports that have shown that IGFBP5 inhibits cell proliferation and differentiation in muscle (Ewton et al. 1998), this negative role has been questioned (Duan et al. 2010), showing abundant evidence that points out a positive role in muscle growth (Awede et al. 2002, Gabillard et al. 2006, Lang et al. 2006, Bower et al. 2008, Ren et al. 2008, Bower \& Johnston 2010, Macqueen et al. 2011). Particularly, IGFBP5 promotes muscle differentiation; its absence impairs myogenesis (Ren et al. 2008), and its expression increases with muscle hypertrophy and decreases during muscle atrophy (Awede et al. 2002, Lang et al. 2006). In fish muscle, only positive effects of igfbp 5 have been described, showing that amino acids alone, as well as the combination of amino acids and Igf1 or Igf2, promote igfbp 5 expression in differentiated myogenic cells (Bower \& Johnston 2010), supporting the fact that pro-anabolic molecules (i.e. Gh and Igf1) increase igfbp 5 expression, as was previously shown in mammals (Lang et al. 2006). In the fine flounder, igfbp 5 expression decreases under nutritional catabolic periods of fasting and increases during favorable nutritional anabolic periods of refeeding, similar to previous reports in other fish species, supporting the idea that Igfbp5 has a positive role in muscle (Gabillard et al. 2006, Bower et al. 2008, Macqueen et al. 2011).

IGFBP6 is unique among IGFBPs for its IGF2-binding specificity, showing 50- to 100-fold higher affinity for IGF2 than IGF1 (Bach 2005). This binding protein inhibits the actions of both IGF2 and IGF1, with no evidence of potentiating IGF actions (Bach 2005). In fish, similar findings have been reported, showing that the overexpression of igfbp 6 generates different growth disorders, associated with a delay in corporal size and normal development of somites in zebra fish embryos (Wang et al. 2009). Studies on muscle-derived igfbp 6 have been very limited and show that igfbp 6 is present in catabolic periods and in quiescent cells (Ewton \& Florini 1995). In fish, similar results have been observed, showing that igfbp 6 is highly expressed in quiescent satellite cells and its expression decreases throughout myogenesis (Bower \& Johnston 2010). Interestingly, in the fine flounder, igfbp 6 expression remains stable during fasting and decreases during short-term refeeding but not during long-term refeeding. Previous reports on skeletal muscle of fish show that igfbp 6 expression also decreases during refeeding, but this change was observed during long-term refeeding (Gabillard et al. 2006, Bower et al. 2008). Thus, although igfbp6 expression in fish muscle decreases during refeeding, this occurs in different periods, showing that igfbp 6 shows a different temporal expression in different fish species and that this Igfbp is acting as a negative regulator of Igf1 actions in muscle.

\section{Integration of the Igf system in fish skeletal muscle during fasting and refeeding}

The components of the Igf system are in a dynamic and organized balance in skeletal muscle. Considering that Igfbps present a complex physiology, an integrative approach of the results, rather than individual interpretation of them, is more appropriate. In this context, the present results of igfbps were placed into an endocrine framework of growth in muscle, compiling the present information with our previous reports in order to have an integrative perspective of the endocrine system of growth in the skeletal muscle of a nonmammalian species. We suggest that the absence of Igfbp1 in the muscle of the fine flounder may be compensated by the rest of the Igfbps, as has been previously observed when some of the Igfbps are absent (Wood et al. 2000, Ning et al. 2006). During fasting, the low basal production of Igf1 in the fine flounder decreases even further (Fuentes et al. 2012a,b). During this period, the igfbp 4 and igfbp 5 decreased concomitantly with an increase in Igfbp3 (Fig. 5C). Interestingly, different studies on fish have previously suggested that both Igfbp4 and Igfbp5 may be positive regulators of Igf1, being diminished in catabolic conditions (Gabillard et al. 2006, Bower et al. 2008, Bower \& Johnston 2010, Macqueen et al. 2011). On the other hand, Igfbp3 in fish skeletal muscle has not been evaluated until now. We suggest that Igfbp 3 could be acting as a negative modulator of Igf1 in skeletal muscle. Owing to low levels of available Igf1, the PI3K/Akt and MAPK/ERK signaling pathways become inactivated, reducing growth in the fine flounder (Fuentes et al. 2011). During short-term refeeding, muscle-derived Igf1 increases drastically in this species (Fuentes et al. 2012a,b). During this period, igfbp2, 3, and 6 decrease, suggesting inhibitory actions of these Igfbps, as has 
been previously pointed out in fish (Duan et al. 1999, Gabillard et al. 2006, Bower et al. 2008, Wang et al. 2009, Macqueen et al. 2011). Interestingly, during this period, igfbp 5 increases significantly. Therefore, we suggest that Igf1 would be more available to Igf1r, and PI3K/Akt and MAPK/ERK become strongly reactivated, restoring myogenic activity as we previously reported (Fuentes et al. 2011). Thus, in this stage, positive signals may be exceeding negative signals, promoting a strong catchup growth, as is observed during the first stages of refeeding in the fine flounder (Fuentes et al. 2011, 2012a,b). During long-term refeeding, low production of local igf1 is restored (Fuentes et al. 2012a,b). igfbp 4 and igfbp 5 increase even further than basal levels during this period, concomitant with an increase in igfbp 2 and igfbp 6 (Fig. 5C). Interestingly, contents of igfbp 4 and igfbp 5 are higher than igfbp 2 and igfbp 6 at the end of long-term refeeding. These results suggest that different Igfbps might be competing by Igf1, promoting growth, but more attenuated, as has been previously observed in this species full-compensating growth at the end of refeeding (Fuentes et al. 2011, 2012a,b).

\section{Supplementary data}

This is linked to the online version of the paper at http://dx.doi.org/10.1530/ JOE-12-0057.

\section{Declaration of interest}

The authors declare that there is no conflict of interest that could be perceived as prejudicing the impartiality of the research reported.

\section{Funding}

This work was supported by Fondo Nacional de Desarrollo Científico y Tecnologico (FONDECYT) Grant 1090416 (to A M), Universidad Andres Research Bello Fund DI-14-11/I (to E N F).

\section{Acknowledgements}

The authors thank Juan Manuel Estrada for technical assistance in the Centro de Investigacion Marina de Quintay (Chile); Dr Neil I Bower and Dr Daniel J Macqueen (University of St Andrews, St Andrews, Scotland) for offering advice on the quantitative PCR assays; and Ashley VanCott, BA (The University of Nevada, Reno, USA) for improving and correcting the English of the manuscript.

\section{References}

Amaral IP \& Johnston I 2011 Insulin-like growth factor (IGF) signalling and genome-wide transcriptional regulation in fast muscle of zebrafish following a single-satiating meal. Journal of Experimental Biology 214 2125-2139. (doi:10.1242/jeb.053298)

Awede B, Thissen J, Gailly P \& Lebacq J 1999 Regulation of IGF-I, IGFBP-4 and IGFBP-5 gene expression by loading in mouse skeletal muscle. FEBS Letters 461 263-267. (doi:10.1016/S0014-5793(99)01469-6)

Awede BL, Thissen J \& Lebacq J 2002 Role of IGF-I and IGFBPs in the changes of mass and phenotype induced in rat soleus muscle by clenbuterol. American Journal of Physiology. Endocrinology and Metabolism 282 E31-E37.
Bach LA 2005 IGFBP-6 five years on; not so 'forgotten'? Growth Hormone \& IGF Research 15 185-192. (doi:10.1016/j.ghir.2005.04.001)

Bayol S, Loughna PT \& Brownson C 2000 Phenotypic expression of IGF binding protein transcripts in muscle, in vitro and in vivo. Biochemical and Biophysical Research Communications 273 282-286. (doi:10.1006/bbrc. 2000.2667)

Bower NI \& Johnston IA 2010 Transcriptional regulation of the IGF signalling pathway by amino acids and insulin-like growth factors during myogenesis in Atlantic salmon. PLoS ONE 5 (6) e11100. (doi:101371/journalpone 0011100)

Bower N, Taylor R \& Johnston I 2008 Switching to fast growth: the insulinlike growth factors (IGF) system in skeletal muscle of Atlantic salmon. Journal of Experimental Biology 211 3859-3870. (doi:10.1242/jeb.024117)

Bustin SA, Benes V, Nolan T \& Pfaffl MW 2009 Quantitative real-time RT-PCR - a perspective. Journal of Molecular Endocrinology 34 597-601. (doi:10.1677/jme.1.01755)

Caraux G \& Pinloche S 2005 PermutMatrix: a graphical environment to arrange gene expression profiles in optimal linear order. Bioinformatics $\mathbf{2 1}$ 1280-1281. (doi:10.1093/bioinformatics/bti141)

Chen JY, Chen JC, Huang WT, Liu CW, Hui CF, Chen TT \& Wu JL 2004 Molecular cloning and tissue-specific, developmental-stage-specific, and hormonal regulation of IGFBP3 gene in zebrafish. Marine Biotechnology 6 1-7. (doi:10.1007/s10126-002-0115-9)

Chen W, Wang Y, Li W \& Lin H 2010 Insulin like growth factor binding protein-2 (IGFBP-2) in orange-spotted grouper, Epinephelus coioides: molecular characterization, expression profiles and regulation by $17 \beta$-estradiol in ovary. Comparative Biochemistry and Physiology. Part B, Biochemistry 157 336-342. (doi:10.1016/j.cbpb.2010.08.001)

Cheng R, Li W \& Wu JL 2002 Different temporal expressions of Tilapia (Oreochromis mossambicus) insulin-like growth factor-I and IGF binding protein-3 after growth hormone induction. Marine Biotechnology 4 218-225. (doi:10.1007/s10126-002-0014-0)

Clemmons DR 1998 Role of insulin-like growth factor binding proteins in controlling IGF actions. Molecular and Cellular Endocrinology 140 19-24. (doi:10.1016/S0303-7207(98)00024-0)

Dai W, Kamei H, Zhao Y, Ding J, Du Z \& Duan C 2010 Duplicated zebrafish insulin-like growth factor-binding protein-5 genes with split functional domains: evidence for evolutionarily conserved IGF binding, nuclear localization, and transactivation activity. FASEB Journal 24 2020-2029. (doi:10.1096/fj.09-149435)

Damon SE, Haugk KL, Birnbaum RS \& Quinn LS 1998 Retrovirally mediated overexpression of insulin-like growth factor binding protein 4: evidence that insulin-like growth factor is required for skeletal muscle differentiation. Journal of Cellular Physiology 175 109-120. (doi:10.1002/ (SICI) 1097-4652(199804) 175:1 < 109::AID-JCP12>3.0.CO;2-6)

Domené HM, Hwa V, Jasper HG \& Rosenfeld RG 2011 Acid-labile subunit (ALS) deficiency. Best Practice \& Research. Clinical Endocrinology \& Metabolism 25 101-113. (doi:10.1016/j.beem.2010.08.010)

Duan C \& Xu Q 2005 Roles of insulin-like growth factor (IGF) bindings proteins in regulation IGF actions. General and Comparative Endocrinology 142 44-52. (doi:10.1016/j.ygcen.2004.12.022)

Duan C, Ding J, Li Q, Tsai W \& Pozios K 1999 Insulin-like growth factor binding protein 2 is a growth inhibitory protein conserved in zebrafish. PNAS 96 15274-15279. (doi:10.1073/pnas.96.26.15274)

Duan C, Ren H \& Gao S 2010 Insulin-like growth factors (IGFs), IGF receptor, and IGF-binding proteins: roles in skeletal muscle growth and differentiation. General and Comparative Endocrinology 167 344-351. (doi:10.1016/j.ygcen.2010.04.009)

Eppler E, Caelers A, Shved N, Hwang G, Rahman A, Maclean N, Zapf J \& Reinecke M 2007 Insulin-like growth factor I (IGF-I) in a growthenhanced transgenic (GH-overexpressing) bony fish, the tilapia (Oreochromis niloticus): indication for a higher impact of autocrina/paracrina than of endocrine IGF-I. Transgenic Research 16 479-489. (doi:10.1007/s11248007-9093-z)

Ewton DZ \& Florini JR 1995 IGF-binding proteins-4, -5 and -6 may play specialized roles during L6 myoblast proliferation and differentiation. Journal of Endocrinology 144 539-553. (doi:10.1677/joe.0.1440539) 
Ewton DZ, Coolican SA, Mohan S, Chernausek SD \& Florini JR 1998 Modulation of insulin-like growth factor actions in L6A1 myoblasts by insulin-like growth factor binding protein (IGFBP)-4 and IGFBP-5: a dual role for IGFBP-5. Journal of Cellular Physiology 177 47-57. (doi:10.1002/ (SICI) 1097-4652(199810)177:1 < 47::AID-JCP5 > 3.0.CO;2-E)

Firth S \& Baxter R 2002 Cellular actions of the insulin-like growth factor binding proteins. Endocrine Reviews 23 824-854. (doi:10.1210/er.2001-0033)

Foulstone EJ, Savage PB, Crown AL, Holly JMP \& Stewart CEH 2003 Role of insulin-like growth factor binding protein-3 (IGFBP-3) in the differentiation of primary human adult skeletal myoblasts. Journal of Cellular Physiology 195 70-79. (doi:10.1002/jcp.10227)

Fox B, Breves J, Davis L, Pierce A, Hirano T \& Gordon-Grau E 2010 Tissue-specific regulation of the growth hormone/insulin-like growth factor axis during fasting and re-feeding: Importance of muscle expression of IGF-I and IGF-II in the tilapia. General and Comparative Endocrinology 166 573-580. (doi:10.1016/j.ygcen.2009.11.012)

Fuentes EN, Bjorsson BTh, Valdés JA, Einarsdottir EI, Lorca B, Álvarez M \& Molina A 2011 The IGF-I/PI3K/Akt and the IGF-I/MAPK/ERK pathways in vivo in skeletal muscle are regulated by nutrition and contribute to somatic growth in the fine flounder. American Journal of Physiology. Regulatory, Integrative and Comparative Physiology 300 R1532-R1542. (doi:10.1152/ajpregu.00535.2010)

Fuentes EN, Einarsdottir IE, Valdes JA, Alvarez M, Molina A \& Bjornsson BTh $2012 a$ Inherent growth hormone resistance in the skeletal muscle of the fine flounder is modulated by nutritional status and is characterized by high contents of truncated GHR, impairment in the JAK2/STAT5 signaling pathway, and low IGF-I expression. Endocrinology 153 283-294. (doi:10.1210/ en.2011-1313)

Fuentes EN, Kling P, Einarsdottir IE, Alvarez M, Valdés JA, Molina A \& Björnsson BTh $2012 b$ Plasma leptin and growth hormone levels in the fine flounder (Paralichthys adspersus) increase gradually during fasting and decline rapidly after refeeding. General and Comparative Endocrinology. In press. (doi:10.1016/j.ygcen.2012.02.019)

Gabillard JC, Kamangar B \& Monserrat N 2006 Coordinated regulation of the GH/IGF system genes during refeeding in rainbow trout (Oncorhynchus mykiss). Journal of Endocrinology 191 15-24. (doi:10.1677/joe.1.06869)

Hwa V, Oh Y \& Rosenfeld R 1999 The insulin-like growth factor binding protein (IGFBP) superfamily. Endocrine Reviews 20 761-787. (doi:10.1210/ er.20.6.761)

James PL, Jones SB, Busby WH, Clemmons DR \& Rotwein P 1993 A highly conserved insulin-like growth factor-binding protein (IGFBP)-5 is expressed during myoblast differentiation. Journal of Biological Chemistry 268 22305-22312.

Jones J \& Clemmons D 1995 Insulin-like growth factors and their binding proteins: Biological actions. Endocrine Reviews 16 3-34.

Kamangar BB, Gabillard J \& Bobe J 2006 Insulin-like growth factor-binding protein (IGFBP)-1, $-2,-3,-4,-5$, and -6 and IGFBP-related protein 1 during rainbow rout postvitellogenesis and oocyte maturation: molecular characterization, expression profiles, and hormonal regulation. Endocrinology 147 2399-2410. (doi:10.1210/en.2005-1570)

Kamei H, Lu L, Jiao S, Li Y, Gyrup C, Laursen L, Oxvig C, Zhou J \& Duan C 2008 Duplication and diversification of the hypoxia-inducible IGFBP-1 gene in Zebrafish. PLoS ONE 3 e3091. (doi:10.1371/journal.pone. 0003091)

Kajimura S \& Duan C 2007 Insulin-like growth factor (IGF) binding protein-1: an evolutionarily conserved fine tuner of IGF actions under catabolic conditions. Journal of Fish Biology 71 309-325. (doi:10.1111/ j.1095-8649.2007.01606.x)

Kajimura S, Aida K \& Duan C 2005 Insulin-like growth factor-binding protein-1 (IGFBP-1) mediates hypoxia-induced embryonic growth and developmental retardation. PNAS 102 1240-1245. (doi:10.1073/pnas. 0407443102)

Lang CH, Krawiec BJ, Huber D, McCoy JM \& Frost RA 2006 Sepsis and inflammatory insults downregulate IGFBP-5, but not IGFBP-4, in skeletal muscle via a TNF-dependent mechanism. American Journal of Physiology. Regulatory, Integrative and Comparative Physiology 290 R963-R972. (doi:10.1152/ajpregu.00684.2005)
Li M, Li Y, Lu L, Wang X, Gong Q \& Duan C 2009 Structural, gene expression, and functional analysis of the Fugu (Takifugu rubripes) insulinlike growth factor binding protein-4 gene. American Journal of Physiology. Regulatory, Integrative and Comparative Physiology 296 R558-R566. (doi:10.1152/ajpregu.90439.2008)

Macqueen D, Kristjánsson JM, Paxton CG, Vieira VL \& Jhonston IA 2011 The parallel evolution of dwarfism in Arctic charr is accompanied by adaptative divergence in m-Tor-pathway gene expression. Molecular Ecology 20 3167-3184. (doi:10.1111/j.1365-294X.2011.05172.x)

Maures T \& Duan C 2002 Structure, developmental expression, and physiological regulation of zebrafish IGF binding protein-1. Endocrinology 143 2722-2731. (doi:10.1210/en.143.7.2722)

Muller PY, Janovjak H, Miserez AR \& Dobbie Z 2002 Processing of gene expression data generated by quantitative real-time RT-PCR. Biotechniques 32 1372-1378.

Ning Y, Alwin G, Schuller P, Bradshaw S, Rotwein P, Ludwig T, Frystyk J \& Pintar JE 2006 Diminished growth and enhanced glucose metabolism in triple knockout mice containing mutations of insulin-like growth factor binding protein-3, -4, and -5. Molecular Endocrinology 20 2173-2186. (doi:10.1210/me.2005-0196)

Ning Y, Schuller AG, Conover CA \& Pintar JE 2008 Insulin-like growth factor (IGF)-binding protein-4 is both a positive and negative regulator of IGF activity in vivo. Molecular Endocrinology 22 1213-1225. (doi:10.1210/ me.2007-0536)

Ocampo Dasa D, Sundstrom G, Bergqvist CA, Duan C \& Larhammar D 2011 Evolution of the insulin-like growth factor binding protein (IGFBP) family. Endocrinology 152 2278-2289. (doi:10.1210/en.2011-0047)

Pampusch MS, Kamanga-Sollo E, White ME, Hathaway MR \& Dayton WR 2003 Effect of recombinant porcine IGF-binding protein-3 on proliferation of embryonic porcine myogenic cell cultures in the presence and absence of IGF-I. Journal of Endocrinology 176 227-235. (doi:10.1677/joe.0.1760227)

Pedroso F, Fukada H \& Masumoto T 2009a Molecular characterization, tissue distribution patterns and nutritional regulation of IGFBP-1, $-2,-3$ and -5 in yellowtail, Seriola quinqueradiata. General and Comparative Endocrinology 161 344-353. (doi:10.1016/j.ygcen.2009.01.010)

Pedroso F, Fukada H \& Masumoto T 2009b In vivo and in vitro effect of recombinant salmon growth hormone treatment in IGF-I and IGFBPs in yellowtail Seriola quinqueradiata. Fisheries Science 75 887-894. (doi:10.1007/ s12562-009-0107-z)

Pérez-Bercoff A, Koch J \& Burglin T 2006 LogoBar: bar graph visualization of protein logos with gaps. Bioinformatics 22 112-114. (doi:10.1093/ bioinformatics/bti761)

Peterson BC \& Waldbieser GC 2009 Effects of fasting on IGF-I, IGF-II, and IGF-binding protein mRNA concentrations in channel catfish (Ictalurus punctatus). Domestic Animal Endocrinology 37 74-83. (doi:10.1016/j. domaniend.2009.03.004)

Rahman MS \& Thomas P 2011 Characterization of three IGFBP mRNAs in Atlantic croaker and their regulation during hypoxic stress: potential mechanisms of their upregulation by hypoxia. American Journal of Physiology. Endocrinology and Metabolism 301 E637-E648. (doi:10.1152/ajpendo.00168. 2011)

Ren HX, Yin P \& Duan CM 2008 IGFBP-5 regulates muscle cell differentiation by binding to IGF-II and switching on the IGF-II autoregulation loop. Journal of Cell Biology 182 979-991. (doi:10.1083/jcb. 200712110)

Rodgers BD, Roalson EH \& Thompson C 2008 Phylogenetic analysis of the insulin-like growth factor binding protein (IGFBP) and IGFBP-related protein gene families. General and Comparative Endocrinology 155 201-207. (doi:10.1016/j.ygcen.2007.04.013)

Shimizu M, Suzuki S, Horikoshi M, Hara A \& Dickhoff W 2011 Circulating salmon $41-\mathrm{kDa}$ insulin-like growth factor binding protein (IGFBP) is not IGFBP-3 but an IGFBP-2 subtype. General and Comparative Endocrinology 171 326-331. (doi:10.1016/j.ygcen.2011.02.013)

Siharath K, Nishioka R \& Bern HA 1995 Regulation of IGF-binding protains (IGFBPs) by growth hormone (GH) in the striped bass, Morone saxatilis. Molecular Marine Biology and Biotechnology 135 171-178.

Sjögren K, Liu JL, Blad K, Skrtic S, Vidal O, Wallenius V, LeRoith D, Törnell J, Isaksson OG, Jansson JO et al. 1999 Liver derived insulin-like 
growth factor I (IGF-I) is the principal source of IGF-I in blood but is not required for postnatal body growth in mice. PNAS 96 7088-7092. (doi:10.1073/pnas.96.12.7088)

Sun C, Tao Y, Jiang X \& Zou S 2011 IGF binding protein 1 is correlated with hypoxia-induced growth reduce and developmental defects in grass carp (Ctenopharyngodon idellus) embryos. General and Comparative Endocrinology 172 409-415. (doi:10.1016/j.ygcen.2011.04.005)

Tamura K, Peterson D, Peterson N, Stecher G, Nei M \& Kumar S 2011 MEGA5: molecular evolutionary genetics analysis using maximun likelihood, evolutionary distance, and maximun parsimony methods. Molecular Biology and Evolution 28 2731-2739. (doi:10.1093/molbev/ msr121)

Velloso CP 2008 Regulation of muscle mass by growth hormone and IGF-I. British Journal of Pharmacology 154 557-568. (doi:10.1038/bjp.2008.153)

Wang X, Lu L, Li Y, Li M, Chen C, Feng Q, Zhang C \& Duan C 2009 Molecular and functional characterization of two distinct IGF binding protein- 6 genes in zebrafish. American Journal of Physiology. Regulatory, Integrative and Comparative Physiology 296 R1348-R1357. (doi:10.1152/ajpregu.90969.2008)

Wood TL, Rogler LE, Czick ME, Schuller AG \& Pintar JE 2000 Selective alterations in organ sizes in mice with a targeted disruption of the insulin-like growth factor-binding protein-2 gene. Molecular Endocrinology 14 1472-1482. (doi:10.1210/me.14.9.1472)

Wood AW, Schlueter PJ \& Duan C 2005 Targeted knockdown of insulin-like growth factor binding protein-2 disrupts cardiovascular development in Zebrafish embryos. Molecular Endocrinology 19 1024-1034. (doi:10.1210/ me.2004-0392)
Yakar S, Liu JL, Stannard B, Butler A, Accili D, Sauer B \& LeRoith D 1999 Normal growth and development in the absence of hepatic insulin-like growth factor I. PNAS 96 7324-7329. (doi:10.1073/pnas.96.13.7324)

Yamada PM \& Lee KW 2009 Perspectives in mammalian IGFBP-3 biology: local vs. systemic action. American Journal of Physiology. Cell Physiology 296 C954-C976. (doi:10.1152/ajpcell.00598.2008)

Zhong Y, Lu L, Zhou J, Li Y, Liu Y, Clemmons DR \& Duan C 2011 IGF binding protein 3 exerts its ligand-independent action by antagonizing BMP in zebrafish embryos. Journal of Cell Science 124 1925-1935. (doi:10.1242/jcs.082644)

Zhou R, Flaswinkel H, Schneider MR, Lahm H, Hoeflich A, Wanke R \& Wolf E 2004 Insulin-like growth factor-binding protein-4 inhibits growth of the thymus in transgenic mice. Journal of Molecular Endocrinology 32 349-364. (doi:10.1677/jme.0.0320349)

Zhou J, Li W, Kamei H \& Duan C 2008 Duplication of the IGFBP-2 Gene in Teleost Fish: Protein Structure and Functionality Conservation and Gene Expression Divergence. PLoS ONE 3 (8) e3091. (doi:10.1371/journal. pone.0003091)

\section{Received in final form 2 April 2012 \\ Accepted 12 April 2012 \\ Made available online as an Accepted Preprint 12 April 2012}

